\title{
Pebedaan Aspirasi Karir Antara Wanita Yang Sudah Menikah dan Yang Belum Menikah Pada Pegawai Negeri Sipil
}

\author{
Retno Setyowati \\ Universitas Islam Indonesia \\ Bagus Riyono \\ Universitas Gadjah Mada
}

\begin{abstract}
This study examined difference in career aspiration between married and single women who work for government offices. Subjects of the study were government employee at Pemda Kulon Progo with a total number of 120 persons; 84 of them were manied with working husband's and 36 were single working women. Data were collected through questionnaire consisting Career Aspiration Scale (Wisnuwardhani 1998) and demographic data questionnaire. The data were analyzed with $t$-test for independent samples and product moment correlation analysis. The result shows that there is no significant difference on career aspiration between married-women and single-women working for government offices ( $t=1,379 ; p>0,05)$. Other results reveal that fevel of education influences the magnitude of career aspiration $(r=0,269 ; p<0,01)$; also there is a negative corratation between age and career aspiration $(=-0,365 ; \rho<0,01)$; length of tenure and career aspiration $(r=-0,315$; $p<0,01)$; and number of children with career aspiration $(r=-0,307 ; p<0,01)$.
\end{abstract}

Keywords : Career aspiration, Married and Single women

\section{PENGANTAR}

$\mathrm{P}$ embangunan sumber daya manusia sangat penting dan strategis dalam menghadapi persaingan global. Jumlah wanita Indonesia yang menempati lebih dari separoh penduduk Indonesia merupakan salah satu aset pembangunan yang harus di-kembangkan. Seiring dengan kemajuan pembangunan maka terbuka peluang dan kesempatan bagi wanita untuk ber-partisipasi disektor publik.

Pada dasawarsa terakhir ini terlihat bahwa pola kehidupan tradisional sudah bergerak mendekati pola kehidupan yang lebih maju,

sehingga tidak mengherankan lagi apabila seorang wanita berfungsi ganda sebagai ibu rumah langga dan juga sebagai wanita karir. Ada berbagai hal yang mendorong seorang wanita untuk bekerja d luar rumah, mungkin karena kebutuhan hidup yang semakin bertambah, sehingga seorang issri menganggap perlu membantu mencari tambahan penghasilan rumah tangga atau bisa juga karena kesadaran sebagai anggota masyarakat, merasa berkewajiban mengabdikan diri sesuai dengan kemampuan dan keahlian (Azahari, 1999). 
Adanya pergeseran dan perluasan peran wanita ini menurutAlawiyah (Wulandari, 1998) disebabkan keinginan wanita untuk melakukan emansipasi, adanya dampak pendidikan pula oleh motif ekonomi, sehingga dapat dikatakan bahwa wanita memiliki peluang yang sama dengan kaum laki - iaki dalam hal pendidikan dan pekerjaan.

Sejalan dengan kemajuan tingkat pendidikan wanita dan semakin tersedianya kesempatan kerja yang lebih luas bagi wanita, partisipasi angkatan kerja wanita dalam pembangunan ekonomi meningkat dari waktu ke waktu. Ini dapat dilihat dari semakin banyaknya jumlah wanita yang beker ja baik pada sektor swasta. Pada sektor pemerintahan maupun pada sektor swasta. Pada sektor pemerintah-an tampak bahwa pemerintah memberikan kesempatan pada setiap warga negara untuk melamar sebagai Pegawai Negeri Sipil sepanjang memenuhi syarat yang ditentukan. Pengangkatan Pegawai Negeri Sipil ini harus dilaksanakan secara secara obyektif dan selektif sehingga dapat menimbulkan kompetisi dan kegairahan dalam bekerja. Meskipun secara absolut tingkat partisipasi angkatan kerja wanita masih lebih rendah dibandingkan laki -laki, namun secara relatif tingkat partisipasi angkatan kerja wanita meningkat lebih cepat dibandingkan laki-laki.

Namun demikian, meningkatnya status wanita dalam masyarakat, terutama bagi wanita yang sudah menikah, dapat menimbulkan gangguan ketenangan rumah tangga, yaitu sering terjadinya anggapan yang kurang mengenakkan bagi wanita karir. Karir bagi wanita merupakan pilihan hidup sehingga harus dipersiapkan secara matang dan dijalankan secara profesional. Apabila wanita sud ah mencurahkan dirinya pada karir maka ia akan kesulitan menjalankan fungsinya sebagai ibu rumah tangga. Sebagaimana diketahui bahwa karir bukanlah aktivitas sambilan yang bisa ditinggalkan sewaktu waktu karena adanya ikatan dengan pihak lain untuk mencurahkan seluruh perhatiannya pada karirnya itu.
Dahri (1993) mengatakan salah satu ciri dari wanita karir adalah sebagai berikut: bertugas pada bidang pekerjaan laki - laki misalnya menjadi eksekutif, militer, direktur dan bidang lainnya; Tugas - tugas yang harus diselesaikannya memerlukan perhatian serius, sehingga membutuhkan waktu tesendiri; lokasi bekerja wanita karif bukan di dalam rumah tetapi di luar rumah.

Akibat dari tu gas - tug as terse but wanita kariryang merangkap tugas sebagai ibu rumah tangga akan memiliki beban yang cukup berat. Intensitas pelayanan kepada suami jug a menjadi berkurang karena karena ia sendiri juga butuh dilayani karena kelelahan sehabis bekerja. Sedyono \& Hasibuan (1998) mengemukakan bahwa salah satu tantangan terbesar bagi wanita karir adalah persepsi tentang kekurangan waktu, perasaan bahwa ada perbedaan yang sang at besar antara waktu yang dimiliki dengan jumlah tugas yang harus dikerjakan.

Meskipun demikian kaum wanita yang memiliki keinginan untuk maju, ingin mengembangkan diri dan ingin melakukan emansipasi, berusaha memanfaatkan kesempatan kerja yang diberikan. Jadi mereka tidak hanya sekedar bekerja tetapi juga berkarir. Semua orang dalam hidupnya tentu mempunyai suatu harapan untuk lebih baik daripada waktu lampau ataupun waktu sekarang. Untuk itu dalam mencapai cita - citanya ini tentu saja dibutuhkan suatu usaha agar dapat mewujudkannya

Semakin terbukanya peluang wanita ini tentu saja menggembirakan telapi tidak dapat kita pungkiri bahwa semua itu menghadapkan wanita karir pada kenyataan yang mau tidak mau harus dipilih yaitu : berkarir di luar rumah, sekaligus menata rumah tangga, berkarir di luar rumah dan menomorduakan urusan rumah tangga; atau berkarirdi luartanpa berumah tangga

Ketiga pernyataan tersebut merupakan konsekuensi logis, namun bagi wanita karir hal ini bukan merupakan hal mudah karena pada dasarnya setiap wanita mendam bakkan rumah tangga yang bahagia. Di lain pihak ia 
juga ingin berkarir diluar rumah untuk memenuhi kebutuhan per-ekonomian rumah tangga, atau kebutuhan aktualisasi dirinya. Berdasarkan uraian diatas maka penulis ingin meneliti "Apakah ada perbedaan aspirasi karir antara wanita yang sudah menikah dengan wanita yang belum menikah pada Pegawai Negeri Sipil

\section{TINJAUAN PUSTAKA}

Pengertian karir dalam Anoraga (1992) d definisikan secara sempit dan luas. Secara sempit karir berarti upaya mencari nafkah, mengembangkan profesi, dan meningkatkan kedudukan, sedangkan secara luas karir merupakan langkah maju sepanjang hidup atau mengukir kehidupan seseorang.

Flippo (1987) mengartikan karir sebagai serangkaian kegiatan kerja yang terpisah tetapi berkaitan, yang memberikan kesinambungan, ketentraman, dan arti dalam hidup seseorang. Karir disadari secara individual, dan dibatasi secara sosial, manusia tidak hanya meniti atau mencetak karir dari pengalaman - pengalaman khusus mereka tetapi kesempatan yang diberikan juga akan mempengaruhinya.

Nasir(1983) mengatakan pekerjaan yang bersifat karir mempunyai empat ciri khusus yaitu:

a. Adanya pendidikan khusus. Karir yang dijalani seseorang harus ditunjang oleh pendidikan yang telah ia peroleh.

b. Merupakan suau panggilan. Mengundang arti bahwa seseorang yang menganggap pekerjaan sebagai suatu karir akan mencurahkan seluruh tenaganya, pikiran, dan waktunya untuk pekerjaan itu agar ia dapat mencapai kemajuan dalam karirnya.

c. Dilakukan sepanjang orang kerja dengan jenjang - jenjang kenaikan kepangkatan (jabatan).

d. Bersifat full time, pekerjaan tersebut berjangka waktu panjang, oleh karena itu diharapkan adanya peningkatan jabatan.

Seseorang akan dikatakan berhasil dalam karirnya apabila ia dapat memenuhi tugas tugas dalam tahap - tahap karir serta mencapai tujuan yang telah ditetapkan sebelumnya. Bray \& Howard (Wisnu-wardani, 1998) mengatakan bahwa hal penting yang menunjang kesuksesan karir adalah kemampuan intelektual, ketrampilan interpersonal dan motivasi untuk maju. Martoyo (1987) mengemukakan faktor - faktor yang mempengaruhi keberhasilan karii seseorang adalah pendidikan formal, pengalaman kerja, sikap atasan, bobot pekerjaan, prestasi kerja, adanya lowongan jabatan dan produktivitas kerja.

Aspirasi berasal dari kata aspire, yang artinya bercita - cita atau menginginkan. Hurtock (1979) mengartikan aspirasi sebagai keinginan meraih sesuatu yang lebih tinggi dari keadaan sekarang. Gulo (1982) menyatakan aspirasi merupakan keinginan yang kuat untuk mencapai tingkat kemampuan tertentu. Gunarsa dan Gunarsa (1983) mengatakan kalau aspirasi sama dengan cita- cita, yaitu mengharapkan sesuatu yang lebih tinggi dengan tujuan untuk memperoleh kemajuan. Sawrey dan Telford (Alsa, 1997) mendefinisikan aspirasi sebagal apa yang ingin dicapai seseorang.

Karir merupakan aktivitas yang berhubungan dengan keja, akan tetapi kehidupan seseorang diluar kerja mempunyai peran yang besar dalam menentukan karir seseorang. Aspirasi karir akan muncul setelah karir terbentuk (Flippo, 1984). Aspirasi karyawan terhadap karirnya ditunjang oleh kebutuhankebutuhan baik dari karyawan maupun dari perusahaan. Kebutuhan individu didasari oleh motivasi internal dan eksternal, sedangkan kebutuhan dari organisasi didasarkan pada kebutuhan perusahaan untuk mendapatkan karyawan yang berprestasi dan bekerja dengan baik.

Aspirasi karyawan menyangkut keinginan untuk mendapatkan kesempatan menduduki jabatan yang lebih tinggi. Keadaan ini merupakan salah satu dari aspek-aspek karir. 
Aspek-aspek karir tersebut menurut Hicks \& Gullet (1987) adalah sebagai berikut:

a. Mengenai jabatan dan pekerjaan.

b. Adanya jabatan yang berkedudukan tetap.

c. Adanya kenaikan pangkat.

d. Adanya PHK berdasarkan sebab-sebab obyektif

Aspirasi karir karyawan pada suatu perusahaan berbeda-beda antara satu sama lain. Beberapa karyawan yang mempunyai orientasi prestasi akan berusaha untuk mendapatkan tanggung jawab yang terus meningkat dan menunjukkan mempunyai anspirasi karir yang tinggi. Dilain pihak beberapa karyawan akan mengutamakan keamanan dan kemudahan kerja sehingga mereka tidak terdorong untuk mendapatkan tingkat pekerjaan yang membutuhkan tanggung jawab yang lebih besar (Strauss \& Sayless, 1991).

Menurut Simamora (1993) karyawan harus didorong untuk mencapai tingkat karir yang lebih tinggi karena aspirasi karir yang tinggi akan menghasilkan kinerja yang lebih tinggi. Selain itu perencanaan dan pengembangan karir yang disusun sesuai dengan aspirasi kiaryawan akan ber-pengaruh pada peningkalan prestasi kerja. Aspirasi karir sangat penting dalam menentukan perjalanan karir seseorang, karena aspirasi karir merupakan variabel yang mempe-ngaruhi dalam pencapaian level pekerjaan yang tinggi. Berdasarkan beberapa uraian diatas aspirasi karir dapat dapat didefinisikan sebagai keinginan atau cita-cita dari seseorang untuk mendapatkan kemajuan dalam bidang pekerjaan dan jabatan.

Strauss \& Sayless (1986) me-nyatakan ada beberapa hal yang mempengaruhi aspirasi karir karyawan antara lain yaitu:

\section{a. Perubahan karir}

Perusahaan harus menyadari bahwa aspirasi kari karyawan berubah karena sebabsebab dari dalam dan luar. Sebab dari dalam misalnya faktor keluarga, kepribadian, sedangkan sebab dari luar misalnya kesempatan untuk promosi, lingkungan kerja.

b. Lokasi pekerjaan

Hal ini menjadi lebih penting dalam perencanaan karyawan karena mencerminkan perhatian yang meningkat terhadap mutu kehidupan.

\section{c. Sistem terbuka}

Sifat pokok dari sistem ini adalah memerikan kebebesan luas bagi karyawan untuk memilih karir mereka.

Aspirasi pada wanita dipengaruhi oleh aspek - aspek sosial yang melingkupi individu. dan dalam beberapa hal dapat membawa pengaruh terhadap aspek - aspek sosial disekitar individu. Pembentukan aspirasi tidak dapat terlepas dari dua hal yaitu : pertama, keinginan untuk mengembangkan diri yatu suatu dorongan yang berasal dari dalam diri. Kedua, keinginan untuk memenuhi tanggung jawab sesuai dengan apa yang diharapkan lingkungan sosial individu (Poerwandari, 1996).

Hurlock (1979) menyatakan bahwa aspirasi wanita lebih banyak berhubungan dengan daya tarik pribadi dan penerimaan sosial. Ginzberg (Winkel, 1997), mengemukakan bahwa wanita sulit untuk memilih orientasi yang baru karena rasa takut akan kehilangan peranan sosial tradisional yang diharapkan masyarakat, lebih - lebih bagi wanita yang maju lebih jauh lagi dengan memberikan prioritas pada pembinaan karir.

Konflik yang terjadi pada wanita karir terlebih lagi yang sudah menikah, mempengaruhi keputusan yang berkenaan dengan karimya temasuk aspirasi karimya, konflik timbul karena seringnya dihadapkan pada pilihan untuk berkanir sebagai salah satu tujuan hidupnya atau menjadi ibu rumah tangga yang baik yang selalu siap mengasuh dan melayani kebutuhan suamidan anak - anaknya (Berz \& Fitzgerald, 1962).

Namun demikian lapangan kerja yang semakin terbuka luas bagi wanita telah membawa perubahan - perubahan nilai dalam masyarakat. Aspirasi pada wanita tidak lagi 
terbatas pada hal - hal yang berhubungan dengan daya tarik pribadi dan penerimaan sosial, apalagi dengan sernakin meningkatnya pendidikan wanita maka semakin terbuka wawasannya untuk meningkatkan aspirasi dan mencapai keberhasilan dalam karir.

Ihromi (1985) mengatakan kesempatan untuk memperoleh pendidikan sangat menguntungkan bagi wanila, karena peluang kerja akan lebih banyak, wawasannya menjadi lebih luas dan kemampuan membimbing serta mengasuh anak-anak akan menjadi meningkat. Pendidikan juga akan meningkatkan kesejahteraan. Wanita yang tidak berpendidikan dapat tertinggal dalam segala kesermpatan.

Dari keterangan di atas maka hipotesis yang diajukan adalah "Ada perbedaan aspirasi karir antara wanita yang sudah menikah mermpunyai aspirasi kari antara wanita yang sudah menikah dengan yang belum menikah, wanita yang belum menikah mempunyai aspirasi karir yang lebih tinggi dari pada yang sudah menikah."

\section{METODE PENELITIAN}

Variabel - variabel dalam penelitian ini adaiah aspirasi karir sebagai variabel tergantung, status perkawinan sebagai variabel bebas serta tingkat pendidikan, usia, masa kerja dan jumlah anak sebagai variabel sertaan.

\section{Subyek Penelitian}

Subyek penelitian ini adalah karyawati Pernda Kulon Progo yang berusia 20-50 tahun, status perkawinan jelas, berpendidikan minimal SLTiAdan telah bekerja minimal satu tahun.

\section{Alat Ukkur}

Penelitian ini menggunakan skala yang dimodifikasi dari skala aspirasi karir dari Wisnuwardani (1998). Uj coba alat ukur d sini menggunakan tryoutterpakai yaitu langsung dikenakan pada subyek yang sesungguhnya. Dari 60 item yang disajikan dinyatakan ada 49 item yang memenuhi syarat untuk dianalisis. Perhitungan reliabilitas dilakukan tiap-tiap bagian dari sub aspek. dengan reliabilitas rata-rata diatas 0,700 dan koefisien korelasi bergerak dari 0, 2569 sampai 0,6822.

\section{Metode Analisis Data}

Analisis data yang digunakan untuk menguji hipotesis dalam penelitian ini menggunakan t-Test for Independent Samples dan korelasi produk moment dari Pearson dengan bantuan fasilitas komputer SPSS 10.0 for Windows.

\section{HASIL ANALISIS}

Hasil analisi menunjukkan bahwa tidak ada perbedaan aspirasi karir yang signifikan antara wanita yang sudah menikah dengan yang belum menikah pada pegawai negeri sipil $(t=1,379 ; p>0,05 ;$ Mean empirik (M) untuk yang belummenikah $=144,3611$ dan 140,7738 untuk yang sudah menikah dengan suami bekerja), berarti hipotesis tidak terbukti.

Hasil analisis tambahan menunjukkan bahwa ada korelasi positif yang sangat signifikan antara tingkat pendidikan dengan aspirasi karir ( $r=0,269 ; p<0,01$ ). Adanya hubungan negatif yang sangat signifikan antara usia dengan aspirasi karir $(r=-0,365 ; p<0,01)$. Terdapat hubungan negatif yang sangat signifikan antara masa kerja dengan aspirasi karir ( $r=-0,315 ; p,<0,01$ ) dan ada hubungan negatif yang sangat signifikan antara jumlah anak dengan aspirasi karir $(-0,37 ; p, 0,01)$.

\section{PEMBAHASAN}

Berdasarkan hasil analisis uj hipotesis terlihat bahwa tidak ada perbedaan aspirasi karir yang signifikan antara wanita yang sudah menikah dengan yang belum menikah. Hal ini ditunjukkan dengan nilai koefisien t sebesar $1,379(p>0,05)$. Dengan demikian hipotesis 
yang diajukan ditolak. Penelitian ini sejalan dengan yang dilakukan oleh Wulandari (1988) dimana wanita karir baik yang sudah menikah ataupun yang belum menikah sama-sama masih memegang teguh nilai-nilai tradisional. Attinya, bisa jadi tidak adanya perbedaan aspirasi mengimplikasikan bahwa pada perempuan, menikah atau tidak menikah, nilai sosial budaya yang tidak meng-harapkan wanita terlalu menomorsatukan karirnya mungkin masih kuat dianut.

Hal ini dapat dipahami karena wanita yang sudah menikah, akan merasa cemas jika keberhasilan dalam karirnya akan mempengaruhi bahkan memporak-poranakan kehidupan rumah tangganya (Hyatt dalam Sahrah, 1995). Dari data deskripsi subyek penelitian, didapatkan bahwa subyek yang sudah menikah semuanya mempunyai suami yang bekerja, akibatnya wanita tidak akan terlalu menggantungkan hidupnya pada pekerjaan (Sanmustani, 1988). Penjelasan lain yang terkesan lebih positif adalah wanita memandang aspek kehidupan baik aspek domestik maupun aspek pekerjaan samasama penting, dan karenanya menginginkan keseimbangan dan menghindari adanya konflik dengan keluarga. Corders, J \& Stephen, C. H (Utomo, 1995) menyatakan bahwa wanita yang belum menikah tidak menerapkan aspirasinya terlalu tinggi karena wanita melewati suatu porses dalam membuat keputusan karirnya dengan mem-pertimbangkan perkawinannya kelak serta rencanarencana keluarga. Para wanita yang semula mempersiapkan untuk berkarir akan menurunkan aspirasinya jika ternyata mereka kesulitan dalam mencari pasangan hidup yang cocok,

Hasil penelitian ini juga menunjukkan bahwa tingkat pendidikan mempunyai korelasi positif yang sangat signifikan dengan aspirasi karir yaitu ditunjukkan oleh nilai $r=0,269$ $(P<0,01)$ Hal ini berarti semakin tinggi tingkat pendidikan seseorang maka aspirasi karir yang ditunjukkan akansemakin tinggi. Demikian pula sebaliknya semiakin rendah tingkat pendidikan seseorang maka akan semakin rendah aspirasi karirnya. Hasil penelitian ini mendukung penelitian yang dilakukan oleh Wisnuwardani (1998) dimana terdapat hubungan positif antara tingkat pendidikan dengan aspirasi karir. Fakta ini didukung oleh pendapat yang dikatakan oleh Guy (Utomo, 1995) yaitu pendidikan dapat meningkatkan aspirasi dan harapan wanita akan penghasilan dan kehidupan yang lebih bakk sehingga mendorongnya masuk angkatan kerja. Untuk miendapatkan hasil analisis yang lebih memuaskan dalam kaitannya maka peneliti melakukan analisa lebih lanjut dengan melihat pengaruh status perkawinan dan tingkat pendidikan terhadap aspirasi karir. Dilihat dari rata-rata angka meannya terlihat bahwa aspirasi karir subyek yang belum menikah dengan tingkat pendidikan SLTA mempunyai nilai mean lebih tinggi drai pada subyek yang berpendidikan D-3, untuk lebih jelasnya dapat dilihat pada lembar lampiran. Fakta ini menu rut Winkel (1997) dikarenakan adanya perbedaan nilai-nilai hidup pada tiaptiap orang. Nilai hidup di sini merupakan bentuk dari beberapa ideal yang dikejar oleh se. seorang dimana dan kapanpun juga, sehingga nilai hidup ini dijadikan pegangan dan sangat menentukan gaya hidup seseorang.

Salah satu faktor yang ikut mempengaruhi aspirasi karir adalah faktor usia yaitu aspirasi karir seseorang akan berkembang sejalan dengan usianya. Dari hasil korelasi Pearson didapatkan bahwa ada hubungan negatif yang sangat signifikan antara usia dengan aspirasi karir $r=-0,365(p<0,001)$, yaitu semakin bertambah usianya maka aspirasi karirnya semakin rendah dan sebaliknya.

Masa kerja mempunyai korelasi negatif yang sangat signifikan dengan aspirasi karir r $=-0,315(p<0,01)$. Masa kerja erat kaitannya dengan pe-ngalaman, semakin lama seseorang bekerja maka la akan lebih mengerti posisinya dan kondisi tempat ia bekerja. Hurlock (1979) menyatakan pe-ngalaman seseor ang mempengaruhi aspirasinya dimana seseorang akan belajar menilai kemampuannya dengan melihat pengalaman. Hasil penelitian ini menunjukkan bahwa 
semakin lama seseorang bekerja maka aspirasi karirnya akan semakin menurun. Hal ini bisa jadi karena seseorang yang tadinya mempunyai aspirasi yang tidak realistik yaitu tidak sesuai dengan kenyataan yang dihadapinya di lokasi tempat bekerja mulai menurunkan aspirasi karimya sejalan dengan bertambahnya usia.

Korelasi antara jumlah anak dengan aspirasi karir mempunyai hubungan negatif yang sangat signifikan $r=-0,307(p<0,01)$, thi berarti semakin banyak jumlah anak yang dimiliki maka aspirasi karimya akan semakin rendah. Dan semakin sedikit jumlah anak yang dimiliki maka aspirasi karirnya akan semakin tinggi. Menurut Frieze (Nainggolan, dkk 1996) hal ini terjadi karena pilihan seorang wanita untuk tetap bekerja sambil mengasuh anak membuatnya berada daiam situasi sulit. Kesulitan ini terutama berkaitan dengan anggapan masyarakat bahwa perempuan dinilai dari prestasi yang dicapai suami atau anaknya, dan bukan oleh dirinya sendirí.

Selain itu masih adanya anggapan tradisional yang menyatakan bahwa urusan domestik merupakan tugas utama seorang wanita. Seorang wanita akan direstui bekerja bila lingkungan menilai hal itu tidak berdampak buruk bagi keharmonisan keluarga atau perkembangan anak. Untuk itu semakin banyak anak yang dimiliki maka beban wanita menjadi semakin bertambah sehingga dalam menetapkan aspirasinya tidak trelalu tinggi.

\section{DAFTAR PUSTAKA}

Alsa, A. 1997. Tingkat Aspirasi dalam Memilih Program Studi di Perguruan Tinggi Ditinjau dari Intelegensia dan Jenis Kelamin. Jurnal Psikologika. Nomor 3 Tahun II. Fakultas Psikologi UII. Yogyakarta.

Anoraga, P. 1992. Psikologi Kerja. Jakarta: PT. Rineka Cipta.

Azahari, R. 1999. Wanita Indonesia dan Masa Depan Bangsa. http.//www.
bkkbn.go.id/mag/Bs-22-06.htm

Betz, N. E \& Fitzgerald, L.f. 1982. The Carrer Psychology of Women. Oriando: Academic Press, !nc.

Dahri, I. 1993. Peran Ganda Wanita Modern. Jakarta: Pustaka al-Kautsar.

Flippo, E.B. 1987. Manajemen Personalia. (ter jemah). Edisi keenam. Jakarta: Erlangga.

Hicks, H.G and Gullet, G.R. 1987. Orga nisasi: Teori dan Tingkah Laku. (terjemah). Jakarta: PT. Bina Ang kasa.

1979. Personality Development. New Delhi: Tata Mc-Graw-Hill Publishing Company, Inc.

Ihromi, T.O. 1985. Peningkatan Peran wanita dalam Kebudayaan Bangsa. Dalam Perjuangan Wanita Indonesia 10 Windu Setelah Kartini 1904-1984. Jakarta: Departemen Penerangan RI.

Martoyo, S. 1987. Manajemen SumberDaya Manusia. Yogyakarta: BPFE.

Nasir, M. 1983. Studi Perbedaan Persepsi Mahasiswa Fakultas Psikologi Terhadap Wanita Karir. Skripsi. (tidak diterbitkan). Fakultas Psikologi UGM Yogyakarta.

Nainggolan, dkk. 1996. Studi Kasus Tentang Faktor-Faktor Yang Mempengaruhi Keputusan untuk Berhenti Bekerja Pada Wanita Setelah Kelahiran Anak Pertama. Jurnal Psikologi dan Masyarakat 2. Jakarta : Gramedia.

Poerwandari, E. 1996. Aspirasi Perempuan Bekerja dan Aktualisainya. Jurnal Psikologi dan Masyarakat 2. Jakarta: Gramedia. 
Sahrah, A. 1995. Ketakutan Sukses Pada Wanita KarirDitinjau dari Peran Jenis, Status, Identitas Diri dan Atribusi Kesuksesan. Disertasi. (tidak diterbit kan). Pasca Sarjana UGM Yogya karta.

Sanmustari, R.B. 1988. Persepsi Terhadap Kerja Pada Karyawan Wanita di Beberapa Instansi Pemerintah d! Beberapa Kotamadya Yogyakarto. (Iaporan Penelitian). Fakultas Psiko logi UGM. Yogyakarta.

Simamora, H. 1993. Manajemen Sumber Daya Manusla. Yogyakarta: STIE YKPN.

Sisginaryani, D. 1994. Hubungan Aspirasi Karir dengan Kecemasan Karir pada karyawan PLN Distribusi Jatim di Surabaya. Skripsi. (tidak diterbitkan). Fakultas Psikoogi UGM Yogyakarta.

Staruss, G and Sayles, L. 1986. Manajemen Personalia: Segi Manusia Dalam Organisasi. Jakarta: PT. Binamann Pressindo.
Utomo, U.h. 1995. Hubungan Antara Persepsi Peran Jenis dengan Aspiras: Karir Kerja Pada Wanita. Skripsi. (tidak diterbitkan). Fakultas Psikologi UGM Yogyakarta.

Winkel, W.S. 1997. Bimbingan Konseling di institusi Pendidikan. Jakarta: Grasindo.

Wisnuwardhani, A. 1998. Perbedaan Aspirasi Karir Karyawan Pria dan Karyawan Wanita yang Berstatus Menikah Pada Bank Dagang Indonesia Cab. Bandar Lampung. Skripsi. (tidak diterbitkan). Fakultas Psikologi UGM Yogyakarta.

Wulandari,A.d. 1998.Hubungan antara sifat Feminin dan Motif Menolak Sukses Pada Wanita Karir. Skripsi. (tidak diterbitkan). Fakultas Psikologi UGM Yogyakarta.

\section{Sumber Dari Internet}

Sedyono \& Hasibuan, C. 1998. Keseim bangan Keluarga-Kerja Mungkinkah? www.lppm.ac id/forum/chsi.htm-11 k. 